\title{
PENGARUH RELIGIUSITAS MAHASISWA UNIVERSITAS ISLAM RIAU TERHADAP KEPUTUSAN MENABUNG DI BANK SYARIAH
}

\author{
Mufti Hasan Alfani ${ }^{1}$ \& Rifa $^{2}$ \\ ${ }^{1 \& 2}$ Fakultas Agama Islam, Universitas Islam Riau \\ Email:muftihasanalfani@fis.uir.ac.id,rifa3764@gmail.com
}

\begin{abstract}
ABSTRAK
Penelitian ini keputusan menabung di Bank Syariah yang dipengaruhi religiusitas mahasiswa Universitas Islam Riau. Salah satunya dapat dilihat dari pengetahuan dan keyakinan tentang Bank Syariah. Banyak yang mengartikan bahwa konsep Bank Syariah dengan Bank Konvensional sama. Padahal hal tersebut merupakan dua hal yang berbeda. Tujuan penelitian ini adalah untuk mengetahui pengaruh religiusitas mahasiswa terhadap keputusan menabung di Bank Syariah. Penelitian ini menggunakan pendekatan deskriptif kuantitatif, dengan jumlah sampel 267 responden. Data yang digunakan dalam penelitian ini adalah data primer dan data sekunder. Data primer diperoleh dari kuesioner yang dibagikan kepada responden. Sedangkan, data sekunder diperoleh dari jurnal, bukubuku yang berkaitan dengan judul penelitian ini. Serta, teknik analisis data yang digunakan dalam penelitian ini adalah analisis regresi linier sederhana dengan menggunakan uji T (Parsial) dan uji Koefisien Determinasi (R2). Hasil penelitian menunjukkan terdapat pengaruh signifikan terhadap keputusan menabung di Bank Syariah. Dengan memperoleh hasil T-hitung $(15,66)>$ T-tabel $(1,97)$, dan nilai signifikansi sebesar $0,000<0,05$. Serta dapat diartikan bahwa terdapat pengaruh signifikan variabel religiusitas (X) terhadap keputusan menabung (Y) secara parsial. Sedangkan, hasil uji koefisien determinasi menunjukkan sebesar $48,1 \%$. Ini berarti bahwa religiusitas mempengaruhi keputusan menabung di Bank Syariah sebesar 48,1\%.
\end{abstract}

Kata Kunci : Religiusitas, Keputusan Menabung, Bank Syariah.

\begin{abstract}
This study decision to saving at a sharia bank is influenced by the religiosity of students at the Islamic University of Riau. One of them can be seen from the knowledge and beliefs about Islamic banks. Many interpret that the concept of Islamic Banks and Conventional Banks is the same. Yet these are two different things. The purpose of this study was to determine the effect of student religiosity on saving decisions in Islamic banks. This study uses a quantitative descriptive approach, with a sample of 267 respondents. The data used in this study are primary data and secondary data. Primary data were obtained from questionnaires distributed to respondents. Meanwhile, secondary data were obtained from journals, books related to the title of this research. Also, the data analysis technique used in this study is simple linear regression analysis using the T test (Partial) and the Coefficient of Determination (R2) test. The results of the study show that there is a significant influence on the decision to save in Islamic banks. By obtaining the results T-count (15.66) > T-table (1.97), and a significance value of $0.000<0.05$. And it can be interpreted that there is a significant influence of the religiosity variable $(X)$ on the decision to save $(Y)$ partially. Meanwhile, the results of the coefficient of determination test showed $48.1 \%$. This means that religiosity affects the decision to save at Islamic banks by $48.1 \%$.
\end{abstract}

Keywords: Religiosity, Saving Decision, Islamic Bank. 


\section{PENDAHULUAN}

Bank Syariah merupakan lembaga keuangan yang berdasarkan prinsip syariah dengan menggunakan akad-akad tertentu yang disepakati di awal akad, dan memiliki tujuan untuk mengumpulkan dana dari investor maupun masyarakat yang nantinya dana tersebut akan disalurkan kembali kepada masyarakat.

Salah satu ciri khas Bank Syariah yang tidak ada pada Bank Konvensional adalah tidak menggunakan bunga dalam operasionalnya. Dalam pandangan Islam bunga merupakan riba, yang berarti pengambilan tambahan dari harta pokok atau modal secara bathil. (Yuliani \& Meliza, 2019).

Bank Syariah memiliki tujuan yang bukan hanya ada pada jumlah nominal investasi tapi juga mencakup jenis, objek, dan tujuannya sendiri. Adapun metodologinya yaitu kerangka syariat dan kaidah-kaidah yang bersumber dari etika dan nilai-nilai syariat Islam yang universal. Berdasarkan hal tersebut, Bank Syariah bekerja sebagai sarana untuk mengumpulkan tabungan masyarakat dan mengembangkannya. (Marinim et al, 2015)

Mahasiswa merupakan golongan masyarakat milenial, yang membutuhkan adanya lembaga keuangan untuk bertransaksi, menabung, dan lain-lain serta berperan dalam pertumbuhan ekonomi negara. (Wardani dan Susanti, 2019)

Universitas Islam Riau sudah bekerja sama dengan Bank Syariah. Ini dapat dilihat pada penggunaan jasa Perbankan Syariah oleh mahasiswa saat melakukan pembayaran uang kuliah setiap semesternya, baik itu pembayaran melalui teller Bank Syariah, $m$ banking maupun mesin ATM.

Religiusitas mahasiswa merupakan salah satu yang mempengaruhi keputusan mahasiswa menjadi nasabah. Mahasiswa dapat menjadi nasabah Bank Syariah, itu berarti tindakan yang sesuai dengan ajaran
Islam dan juga menguntungkan. (Fauzi \& Murniawaty, 2020)

Menurut Islam tingkat religiusitas seseorang secara pasti hanya Allah SWT. yang mengetahui, tetapi pernyataan tentang pengalaman religius-nya dapat dijadikan pijakan awal dari pengukuran religiusitasnya. Peneliti secara khusus tertarik untuk menguji apakah religiusitas mahasiswa Universitas Islam Riau berpengaruh terhadap keputusan menabung di Bank Syariah.

Penelitian ini didukung oleh penelitian sebelumnya yang dilakukan oleh Mu'in (2016) dengan judul studi analisis religiusitas mahasiswa FE UNY yang menabung di Bank Syariah. Dengan tujuan penelitian untuk mengetahui religiusitas dan dimensi religiusitas ideologi, ritualistik, eksperensial, intelektual, dan konsekuensi mahasiswa FE UNY yang menabung di Bank Syariah. Perhitungan metode analisis statistik deskriptif dengan hasil bahwa Pengaruh religiusitas mahasiswa FE UNY yang menabung di Bank Syariah sangat tinggi, dengan skor mean 86,20 kategori $100 \%$. Pada religiusitas dimensi ideologi dan ritualistik mahasiswa FE UNY yang menabung di Bank Syariah juga sangat tinggi, dengan skor mean 19,83 kategori 95\% dan skor mean 17,68 kategori 45\%. Dan pada religiusitas dimensi eksperensial mahasiswa FE UNY yang menabung di Bank Syariah sangat tinggi dan rendah, dengan skor mean 17,53 dengan kategori $30 \%$. Sedangkan pada religiusitas dimensi intelektual mahasiswa FE UNY yang menabung di Bank Syariah sedang, dengan skor mean 14,98 dalam kategori $65 \%$. Serta pada religiusitas dimensi konsekuensi mahasiswa FE UNY yang menabung di Bank Syariah rendah, dengan skor mean 16,20 dengan kategori $45 \%$. Sehingga dapat diambil kesimpulan bahwa mahasiswa yang menabung di Bank Syariah memiliki religiusitas yang sangat tinggi.

Kemudian, pada penelitian yang dilakukan oleh Nurjaenah (2019) yang berjudul pengaruh, religiusitas, keluarga, teman dan status sosial terhadap keputusan 
mahasiswa dalam memilih produk tabungan Bank Syariah. Dengan tujuan penelitian untuk menganalisis pengaruh religiusitas, keluarga, teman dan status sosial terhadap keputusan mahasiswa dalam memilih produk tabungan Bank Syariah serta menganalisis variabel yang paling dominan berpengaruh terhadap keputusan mahasiswa dalam memilih produk tabungan Bank Syariah. Penelitian ini menggunakan metode penelitian regresi linear berganda, dengan hasil mengatakan bahwa variabel religiusitas tidak berpengaruh signifikan terhadap keputusan mahasiswa dalam memilih produk tabungan Bank Syariah, dengan nilai signifikan 0,235. Pada variabel keluarga juga tidak memiliki pengaruh yang signifikan terhadap keputusan mahasiswa dalam memilih produk tabungan Bank Syariah. Sedangkan, variabel teman memiliki pengaruh yang signifikan terhadap keputusan mahasiswa dalam memilih produk tabungan.

Sedangkan, Penelitian yang dilakukan oleh Fathurrohman (2019) yang berjudul pengaruh religiusitas terhadap keputusan menabung di Bank Syariah. Dengan tujuan penelitian untuk mengetahui pengaruh religiusitas nasabah terhadap keputusan menabung di bank BNI Syariah Cabang Bekasi dan menganalisis bagaimana besaran pengaruh religiusitas tersebut. Dari hasil analisis regresi linear sederhana diketahui bahwa Pengaruh religiusitas secara positif berpengaruh terhadap keputusan nasabah menabung. Dengan perhitungan menggunakan uji $\mathrm{F}$ menghasilkan nilai signifikan sebesar $0,000<0,05$, maka $\mathrm{H} 0$ ditolak. Sedangkan, penelitian menggunakan uji koefisien determinasi antara penerapan religiusitas dengan keputusan menabung sebesar 9,3\%. Ini menunjukkan bahwa sebesar 9,3\% keputusan menabung yang terjadi dipengaruhi oleh religiusitas dan sisanya $90,7 \%$ dipengaruhi oleh faktor lain.

\section{TINJAUAN PUSTAKA}

\section{Religiusitas}

Religiusitas memiliki kesamaan dari beberapa istilah, diantaranya kepercayaan, kesalehan, pengabdian dan kesucian. Religiusitas merupakan tingkat keyakinan, praktik agama, pengalaman, pengetahuan agama, dan konsekuensi seseorang dalam berhubungan dengan Allah SWT sebagai upaya untuk mencari makna kehidupan.

Hal yang mendekatkan dan mengantarkan manusia untuk dekat kepada Allah SWT. adalah menjalankan semua perintah Allah SWT. dan meninggalkan semua larangan-Nya. Seperti yang dijelaskan dalam Firman Allah SWT dalam Q.S. AlBaqarah ayat 177 :

Artinya : "Kebajikan itu bukanlah menghadapkan wajahmu ke arah timur dan ke barat, tetapi kebajikan itu ialah (kebajikan) orang yang beriman kepada Allah, hari Akhir, malaikat-malaikat, kitabkitab, dan nabi-nabi, dan memberikan harta yang dicintainya kepada kerabat, anak yatim, orangorang miskin, orang-orang yang dalam perjalanan (musafir), pemintaminta, dan untuk memerdekakan hamba sahaya, yang melaksanakan salat dan menunaikan zakat, orang-orang yang menepati janji apabila berjanji, dan orang yang sabar dalam kemelaratan, penderitaan, dan pada masa peperangan. Mereka itulah orangorang yang benar dan mereka itulah orangorang yang bertakwa”. (Q.S. Al Baqarah ayat 177).

Menurut Ahmad (2020), Cara pandang agama Islam berbeda dari agama yang lainnya. Ajaran Islam merupakan agama yang mengajarkan cara hidup atau jalan menuju Allah SWT yang mencakup seluruh pekerjaan, keyakinan dan keberadaan seorang muslim. Oleh karena itu, dalam Islam tidak ada spiritualitas tanpa kepercayaan dan praktik agama, karena agamalah yang memberikan jalan bagi kehidupan yang baik.

Menurut Glock and Stark dalam Nasrudin (2020) menganalisis religiuitas dalam lima dimensi, yaitu sebagai berikut:

1) Dimensi Keyakinan atau Ideologi.

2) Dimensi Praktik Agama atau Peribadatan. 
3) Dimensi Pengalaman atau Eksperiensial.

4) Dimensi Pengetahuan Agama atau Intelektual.

5) Dimensi Akhlak (Konsekuensi).

Menurut Ancok dan Suroso (2011), berdasarkan lima rumusan keberagamaan yang dikemukakan oleh Glock and Stark terdapat tiga dimensi yang mempunyai kesesuaian dengan Islam, yaitu: 1) Dimensi Akidah atau Keyakinan. 2) Dimensi Syariah atau Praktek Agama. 3) Dimensi Akhlak (Konsekuensi).

\section{Pengambilan Keputusan}

Pengambilan keputusan merupakan proses pemecahan suatu masalah dengan menentukan pilihan dari beberapa alternatif untuk menetapkan suatu tindakan dalam mencapai tujuan yang diinginkan.

Sedangkan, pengertian tabungan menurut Rusdarti dan Kusmuriyanto (2008), yaitu sebagian dari pendapatan masyarakat yang memiliki penghasilan berlebih dan memiliki tabungan dengan melakukan berbagai pendekatan penyelesaian.

Jadi, keputusan penyimpanan adalah tindakan yang diambil dengan sengaja melalui proses mendekati penyelesaian masalah yang terdiri dari pengenalan masalah, menemukan informasi, beberapa pilihan, dan keputusan membeli serta setelah membeli.

Sedangkan, faktor-faktor yang mempengaruhi pengambilan keputusan menurut Kotler dan Amstrong (2001), adalah sebagai berikut: 1) Faktor Budaya, meliputi nilai dasar, persepsi, keinginan dan tingkah laku yang dipelajari seseorang. 2) Faktor Sosial, termasuk kelompok acuan, keluarga, peran dan status. 3) Faktor Pribadi, yang meliputi usia dan tahap siklus hidup, pekerjaan, keadaan ekonomi, gaya hidup, kepribadian dan konsep diri. 4) Faktor Psikologis, yang termasuk motivasi, persepsi, pengetahuan, keyakinan dan pendirian.
Pada konsep jual beli lembaga keuangan sebagai penjual sedangkan nasabah sebagai pembeli (konsumen). Proses melewati beberapa tahapan yang dikonseptualisasikan dalam versi lima tahap proses membeli (Sunyoto, 2014), diantaranya sebagai berikut : 1) Pengenalan Kebutuhan. 2) Pencarian Informasi. 3) Penilaian Alternatif. 4) Keputusan Membeli.

\section{Bank Syariah}

Bank Syariah (Bank Islam) adalah lembaga keuangan yang kegiatannya berdasarkan prinsip syariah dan terbebas dari riba dengan menghilangkan sistem bunga dan menerapkan prinsip-prinsip bagi hasil.

Bank Syariah secara operasional berbeda dengan Bank Konvensional. Salah satu ciri khas Bank Syariah menurut Ismail (2011), diantaranya tidak menerapkan sistem bunga yang memberatkan nasabah, tetapi menerapkan sistem bagi hasil sesuai dengan ketentuan yang ditetapkan diawal akad.

Menurut Suwiknyo (2010), aktivitas operasional Bank Syariah berdasarkan prinsip-prinsip akad dalam fiqih muamalah iqtishadiyah. Adapun fiqih muamalah iqtishadiyah meliputi wadiah, syirkah, ijarah dan al-ajr walumullah. Implementasi fiqih muamalah tersebut terdapat pada tiga produk Bank Syariah, yaitu produk pengumpulan dana, meyalurkan dana dan jasa.

Menurut Andrianto dan Firmansyah (2019), secara garis besar Bank Syariah memiliki tiga fungsi utama yaitu sebagai berikut : 1) Menghimpun dana menghimpun dana dari masyarakat Bank Syariah memiliki fungsi mengumpulkan atau menghimpun dana dari masyarakat yang kelebihan dana. Bank Syariah menghimpun dana dari masyakarat dalam bentuk titipan dengan menggunakan akad al-wadi'ah dan dalam bentuk investasi dengan menggunakan akad al-mudharabah. 2) Penyalurkan dana penyalurkan dana kepada masyarakat Bank Syariah memiliki fungsi mengalirkan dana kepada masyarakat yang membutuhkan, dengan syarat dapat memenuhi ketentuan 
dan persyaratan yang ditetapkan. Dalam hal ini Bank Syariah akan memperoleh pendapatan atau kembali ke atas dana yang disalurkan sesuai ketentuan yang telah ditetapkan diawal akad. 3) Memberikan pelayanan jasa bank selain fungsi menghimpun dan mengalirkan dana kepada masyarakat, Bank Syariah juga memberikan pelayanan jasa kepada nasabahnya. Pelayanan jasa tersebut diberikan dalam rangka untuk memenuhi kebutuhan masyarakat menjalankan aktivitasnya, seperti jasa pengiriman uang (transfer), pemindahbukuan, penagihan surat berharga dan lain sebagainya.

Menurut Ascarya (2008), Bank Syariah menerapkan enam kelompok pola akad, yaitu sebagai berikut: 1) Pola Titipan. Pola titipan terbagi menjadi 2 akad, yaitu: a) Akad Wadi'ah yad Amanah b) Akad Wadi'ah yad Dhamanah. 2) Pola Pinjaman. Pada pola pinjaman Bank Syariah hanya mentapkan dua akad saja, yaitu akad Qardh dan turunannya Qardhul Hasan. Berikut penjelasan mengenai dua akad tersebut, yaitu sebagai berikut: a) Akad Qardh b) Akad Qardhul Hasan. 3) Pola Bagi Hasil. Akad pada pola bagi hasil merupakan akad yang paling penting dan paling utama serta disepakati oleh para ulama. Berikut akad yang ada pada pola bagi hasil yaitu sebagai berikut: a) Musyarakah b) Mudharabah. 4) Pola jual beli Bank Syariah menerapkan tiga akad umum pada pola akad jual beli, diantaranya yaitu: a) Murabahah b) Salam c) Istishna'. 5) Pola Sewa a) Ijarah (akad sewa) b) Ijarah Muntahiya Bittamlik (IMBT). 6) Pola Lainnya. Adapun pola lainnya yang menggunakan akad Bank Syariah adalah, sebagai berikut : a) Wakalah (perwakilan) b) Kafalah (jaminan, beban, tanggungan) c) Hawalah (pengalihan utang) d) Rahn (gadai) e) Sharf (fasilitas penukaran mata uang asing) f) Ujr (imbalan).

Produk-produk Bank Syariah secara garis besar dikelompokkan menjadi empat kelompok (Ascarya, 2008) yaitu: 1) Produk Pendanaan. 2) Produk Pembiayaan. 3)
Produk Jasa Perbankan. 4) Kegiatan Sosial dengan Berbagai Prinsip Syariah.

\section{METODE PENELITIAN}

Penelitian ini menggunakan analisis regresi linier sederhana yang terdiri dari dua variabel yaitu variabel independen (religiusitas) dan variabel dependen (keputusan menabung). Menurut Sugiyono (2012), uji regresi linier sederhana digunakan untuk mengetahui relevan atau tidaknya hubungan variabel independen dengan dependen melalui koefisien regresi.

Menurut Kuncoro (2007), mengukur seberapa jauh kemampuan model dalam menerangkan variasi variabel terikat (dependen/Y) disebut koefisien determinasi. Nilai koefisien determinasi yaitu antara nol dan satu dan untuk menentukan nilai koefisien determinasi dinyatakan dengan nilai $R$ Square. Pada penelitian ini peneliti menggunakan teknik analisis data dengan bantuan alat ukur program SPSS (Statistical Packade for Sosial Science) dengan versi 25.

\section{Populasi dan Sampel}

Populasi dari penelitian ini adalah anggota Populasi seluruh mahasiswa Universitas Islam Riau tahun ajaran 2020/2021 (genap) yang terdiri dari 9 Fakultas dan 35 Program Studi. Dan jumlah populasi penelitiannya yaitu 20.499 mahasiswa.

Teknik pengambilan sampel menggunakan puposive sampling yaitu pengambilan data yang disesuaikan dengan kriteria-kriteria yang telah ditentukan sebelumnya berdasarkan tujuan. Pengambilan jumlah sampel menggunakan rumus Issac-Michael (Zakariah dan Vivi, 2021) yaitu:

$$
\mathrm{n}=\frac{\Lambda^{2} N P Q}{d^{2}(N-1)+X^{2} P Q}
$$

Keterangan:

$$
\begin{aligned}
& \mathrm{n}=\text { Jumlah Sampel } \\
& \mathrm{N}=\text { Jumlah Populasi } \\
& \Lambda=\text { Chi Kuadrat }(10 \%)=2.706
\end{aligned}
$$


$P=$ Proporsi Populasi (0.5)

$\mathrm{Q}=1-\mathrm{P}(1-0.5=0.5)$

d = Derajat Kebebasan (0.5), maka:

$$
\mathrm{n}=\frac{K^{2} N P Q}{d^{2}(N-1)+X^{2} P Q}
$$

$\mathrm{n}=\frac{(2.706)(20.499)(0.5)(0.5)}{(0.05)^{2}(20.499-1)+(2.706)(0.5)(0.5)}$

$\mathrm{n}=\frac{13.867,574}{51.245+0.677}$

$\mathrm{n}=\frac{13.867,574}{51,922}$

$\mathrm{n}=267,085=267$

Jadi, sampel dalam penelitian ini jika dibulatkan sebanyak 267 sampel.

\section{HASIL PENELITIAN PEMBAHASAN}

\section{Uji Normalitas}

Berdasarkan hasil Uji normalitas dalam penelitian ini disajikan dalam bentuk sampel kalimogrov-smirnov, dengan ketentuan data berdistribusi normal apabila nilai tingkat signifikannya $>0,05$. Sebaliknya, dikatakan tidak normal apabila nilai signifikan $<0,05$. Berikut hasil output penelitian dengan SPSS versi 25:

\section{Gambar 1. Hasil Uji Normalitas}

One-sample Kolmogorov-Smirnov Test

\begin{tabular}{|c|c|c|c|}
\hline & & & $\begin{array}{c}\text { Unstandartdized } \\
\text { residual }\end{array}$ \\
\hline \multicolumn{3}{|l|}{$\mathrm{N}$} & 267 \\
\hline \multirow{2}{*}{ Normal Parameters ${ }^{\text {a.b }}$} & Mean & & .000000 \\
\hline & Std. Deviation & & 7.18280709 \\
\hline \multirow[t]{3}{*}{ Most Extreme Differences } & Absolute & & .066 \\
\hline & Positive & & .066 \\
\hline & Negative & & .057 \\
\hline \multicolumn{3}{|l|}{ Test Statistic } & .066 \\
\hline \multicolumn{3}{|l|}{ Asymp. Sig. (2-tailed) } & $.066^{\mathrm{c}}$ \\
\hline \multirow[t]{3}{*}{ Monte Carlo Sig. (2-tailed) } & Sig. & & $.182^{\mathrm{d}}$ \\
\hline & \multirow[t]{2}{*}{$99 \%$ Confidence Interval } & Lower Bound & .172 \\
\hline & & Upper Bound & .192 \\
\hline \multicolumn{4}{|c|}{ a. $\quad$ Test distribution is normal. } \\
\hline \multicolumn{4}{|c|}{ b. Calculated from data. } \\
\hline \multicolumn{4}{|c|}{ c. Lilliefors Significance Correction. } \\
\hline \multicolumn{4}{|c|}{ d. Based on 10000 sampled tables with starting seed 926214481} \\
\hline
\end{tabular}

\section{Sumber : Data Olahan (2021)}

Berdasarkan hasil uji normalitas diatas, maka dapat disimpulkan dari sampel Kolmogorov smirnov menjelaskan bahwa tingkat signifikan $0,182>0,05$, yang artinya data berdistribusi normal.

\section{Uji Linearitas}

Berdasarkan hasil pengujian Linearitas, untuk mengetahui hubungan dua variable yaitu variabel $\mathrm{X}$ (Religiusitas) dan $\mathrm{Y}$ (Keputusan Menabung), apakah linear secara signifikan atau tidak Berikut hasil output pengujian data linearitas: 
Gambar 2. Hasil Uji Linearitas

ANOVA Table

\begin{tabular}{|c|c|c|c|c|c|}
\hline & $\begin{array}{c}\text { Sum of } \\
\text { Squares }\end{array}$ & df & $\begin{array}{c}\text { Mean } \\
\text { Square }\end{array}$ & $\mathbf{F}$ & Sig. \\
\hline \multirow[t]{3}{*}{$\mathrm{Y} * \mathrm{X}$ Between Groups } & 15564.643 & 16 & 972.790 & 22.395 & 1.603 \\
\hline & 12700.367 & 1 & 12700.367 & 292.382 & .000 \\
\hline & 2864.276 & 15 & 190.952 & 4.396 & 2.516 \\
\hline Within Groups & 10859.387 & 250 & 41.790 & & \\
\hline Total & 26424.030 & 266 & & & \\
\hline
\end{tabular}

Sumber : Data Olahan (2021)

Bedasarkan hasil analisis data diatas, dapat disimpulkan bahwa nilai signifikan $(2,52)>0,05$, dan atau F-hitung $(0,911)<$ Ftabel $(1,707)$, ini berarti terdapat hubungan linear secara signifikan antara variabel Religiusitas (X) dengan variabel Keputusan Menabung (Y).

\section{Uji Heteroskedastisitas}

Berdasarkan hasil untuk menguji heteroskedastisitas yaitu dengan melakukan uji glejser. Uji glejser dilakukan dengan menguji nilai absolut residual terhadap variabel independen. Berikut hasil output dari program SPSS versi 25:

\section{Gambar 3. Hasil Uji Heteroskedastisitas}

\begin{tabular}{cccccc}
\hline \multirow{2}{*}{ Model } & \multicolumn{2}{c}{ Unstandardized Coefficients } & $\begin{array}{c}\text { Standardized } \\
\text { Coefficients }\end{array}$ & t & Sig \\
\cline { 2 - 4 } & $\mathbf{B}$ & Std. Error & Beta & & .957 \\
\hline 1 (Constant) & -0.169 & 3.099 & & -.054 & 1.850 \\
\hline Religiusitas & 0.129 & 0.070 & .113 & .065 \\
\hline
\end{tabular}

Sumber : Data Olahan (2021)

Dari hasil output menunjukkan bahwa variabel independen mempunyai nilai signifikan $(0,07)>0,05$, dan T-hitung $(1,85)$ $<$ T-tabel $(1,97)$. Hal ini berarti tidak ada variabel independen signifikan secara sistematis yang mempengaruhi variabel dependen Res_Abs. Maka dapat disimpulkan bahwa tidak terdapat adanya heteroskedastisitas.

\section{Regresi Linear Sederhana}

Untuk mengetahui relevan atau tidaknya hubungan variabel $\mathrm{X}$ dan $\mathrm{Y}$ melalui koefisien regresi, maka pada penelitian ini menggunakan persamaan regresi linier sederhana yaitu $\mathrm{Y}=\mathrm{a}+\mathrm{bX}$. Berikut hasil output analisis regresi linier sederhana sebagai berikut:

Gambar 4. Hasil Uji Analisis Regresi Linear Sederhana

\begin{tabular}{cccccc}
\hline \multirow{2}{*}{ Model } & \multicolumn{2}{c}{ Unstandardized Coefficients } & $\begin{array}{c}\text { Standardized } \\
\text { Coefficients }\end{array}$ & t & Sig \\
\cline { 2 - 4 } & $\mathbf{B}$ & Std. Error & Beta & &. .824 \\
\hline 1 (Constant) & -4.051 & 4.916 & & 15.660 & .000 \\
\hline Religiusitas & 1.734 & .111 & .693 &
\end{tabular}

Sumber : Data Olahan (2021) 
Berdasarkan analisis dari tabel diatas maka dapat disimpulkan Konstanta $=-4,051$, dan Koefisien $X=1,734$. Dengan diperoleh persamaan regresi linier sederhana, yaitu: $\mathrm{Y}=$ $-4,051+1,734 \mathrm{X}$.

\section{Uji T-test}

Berdasarkan hasil pengujian pada tabel Hasil Uji Analisis Regresi Linier Sederhana menjelaskan bahwa Religiusitas (X) memperoleh nilai T-hitung $(15,66)>$ Ttabel $(1,97)$, dan signifikansi sebesar 0,000 $<0,05$. Ini berarti terdapat pengaruh signifikan variabel Religiusitas (X) dengan variabel Keputusan Menabung (Y), serta dapat disimpulkan bahwa Ho ditolak dan H1 diterima.

\section{Koefisien Determinasi $\left(\mathbf{R}^{2}\right)$}

Untuk mengukur berapa persen pengaruh variabel Religiusitas terhadap keputusan menabung di Bank Syariah perlu menguji dengan koefisien determinasi. Adapun hasil output uji determinasi yaitu sebagai berikut:

\section{Gambar 5. Hasil Uji Koefisien Determinasi}

\begin{tabular}{ccccc}
\hline MODEL & $\mathbf{R}$ & $\begin{array}{c}\mathbf{R} \\
\text { Square }\end{array}$ & $\begin{array}{l}\text { Adjusted } \mathbf{R} \\
\text { Square }\end{array}$ & $\begin{array}{c}\text { Std. Error of } \\
\text { the Estimate }\end{array}$ \\
\hline 1. & $.693^{\mathrm{a}}$ & .481 & .479 & 7.196 \\
\hline
\end{tabular}

a. Predictorts : (constant), Religiusitas

b. Dependent variable : keputusan menabung
Berdasarkan Tabel diatas yang menabung di Bank Syariah memiliki menunjukkan nilai R2 sebesar $0,481=$ tingkat religiusitas yang cukup tinggi. 48,1\%. Maka dapat disimpulkan bahwa variabel Religiusitas mempengaruhi variabel Keputusan Menabung di Bank Syariah sebesar $48,1 \%$, dan sisanya sebesar $51,9 \%$ dipengaruhi oleh variabel lain yang tidak masuk pada penelitian ini.

Penelitian ini bermaksud untuk mengungkap pengaruh religiusitas mahasiswa Universitas Islam Riau terhadap keputusan menabung di Bank Syariah secara parsial. Religiusitas merupakan tingkat kepercayaan, intelektual, pemahaman seorang hamba terhadap keyakinan keagamaan yang dianutnya serta dapat mengamalkan dalam kehidupan.

Pengaruh variabel religiusitas terhadap keputusan menabung di Bank Syariah menunjukkan hasil sebesar $48,1 \%$, yang artinya religiusitas mempengaruhi keputusan menabung di Bank Syariah sebesar $48,1 \%$. Sehingga dapat dikatakan bahwa mahasiswa Universitas Islam Riau
Berdasarkan hasil uji dengan SPSS 25, nilai konstanta yang menunjukkan sebesar -4,051. Dapat diartikan bahwa jika nilai religiusitas konstan atau tetap maka keputusan menabung mahasiswa Univeritas Islam Riau di Bank Syariah meningkat sebesar $-4,051$.

Berdasarkan hasil uji hipotesis tentang hasil uji analisis regresi linier sederhana, dapat dilihat bahwa semua koefisien regresi variabel religiusitas bernilai positif. Hal ini menunjukkan religiusitas menaikkan keputusan mahasiswa menabung di Bank Syariah sebesar $1,734 \%$ setiap mengalami kenaikan 1\%. Maka hasil penelitian ini menyatakan bahwa variabel religiusitas memberikan pengaruh positif terhadap keputusan mahasiswa untuk menabung di Bank Syariah. Sedangkan, secara parsial Jika dilihat dari tingkat signifikannya sebesar $0,000<0,05$ dengan nilai T-hitung $(15,66)>\mathrm{T}$-tabel $(1,97)$, ini 
berarti religiusitas mahasiswa Universitas Islam Riau berpengaruh terhadap keputusan menabung di Bank Syariah, maka dapat disimpulkan bahwa $\mathrm{H} 0$ ditolak dan $\mathrm{H} 1$ diterima.

\section{KESIMPULAN}

Berdasarkan penelitian yang telah dibahas diatas maka dapat disimpulkan bahwa religiusitas (X) berpengaruh signifikan terhadap keputusan menabung (Y) di Bank Syariah. dengan tingkat signifikannya sebesar $0,000<0,05$ dan nilai T-hitung $(2,219)>$ T-tabel $(1,992)$, ini berarti religiusitas mahasiswa Universitas Islam Riau berpengaruh terhadap Keputusan Menabung di Bank Syariah dengan H0 ditolak dan $\mathrm{H} 1$ diterima. Pengaruh variabel religiusitas terhadap keputusan menabung di Bank Syariah menunjukkan hasil sebesar $48,1 \%$, yang artinya religiusitas mempengaruhi keputusan menabung di Bank Syariah sebesar 48,1\%. Sehingga dapat dikatakan bahwa mahasiswa Universitas Islam Riau yang menabung di Bank Syariah memiliki religiusitas yang cukup tinggi. Sedangkan, sisanya sebesar 51,9\% dipengaruhi oleh variabel lain yang tidak masuk pada penelitian ini.

\section{DAFTAR PUSTAKA}

Ahmad, J. 2020. Religiusitas, Refleksi Dan Subjektivitas Keagamaan. CV. Budi Utama. Jakarta.

Ancok, D., \& Suroso, F. N. 2011. Psikologi Islami Cetakan ke-8. Pustaka Pelajar. Yogyakarta.

Andrianto., \& Firmansyah, M., 2019. Manajemen Bank Syariah. Qiara Media. Surabaya.

Ascarya. 2008. Akad dan Produk Bank Syariah. Raja Grafindo Persada. Jakarta.

Fathurrohman, Ahmad. 2019. Pengaruh Religiusitas Terhadap Keputusan Menabung Di Bank Syariah (Studi Kasus Pada Bank BNI Syariah Kota Bekasi). Skripsi, Universitas Islam Negeri Syarif Hidayatullah, Jakarta.
Fauzi, A., \& Murniawaty, I. 2020. Pengaruh Religiusitas Dan Literasi Keuangan Syariah Mahasiswa Terhadap Minat Menjadi Nasabah di Bank Syariah, Economic Education Analysis Journal, 9(2), p. 473-486.

Ismail. 2011. Perbankan Syariah. Kencana. Jakarta.

Kotler, P., \& Amstrong, G. 2001. Manajemen Pemasaran, Edisi keduabelas Jilid 1. Erlangga. Jakarta.

Kuncoro, M. 2007. Metode Kuantitatif Teori dan Aplikasi Untuk Bisnis dan Ekonomi. STIM YKPM. Yogyakarta.

Marinim, A., Romdhoni, A. H., \& Fitria, T. N., 2015. Perkembangan Bank Syariah di Indonesia, Jurnal Ilmiah Ekonomi Islam, 1(2), p. 75-87.

Mu'in, Abdul. 2016. Studi Analisis Religiusitas Mahasiswa FE UNY yang Menabung di Bank Syariah. Skripsi, Fakultas Ekonomi Universitas Negeri Yogyakarta, Yogyakarta.

Nasrudin, J. 2020. Refleksi Keberagamaan dalam Sistem Pengobatan Tradisional Masyarakat Pedesaan. PT. Rajagrafindo Persada. Depok.

Nurjaenah. 2019. Pengaruh Religiusitas, Keluarga, Teman dan Status Sosial Terhadap Keputusan Mahasiswa Dalam Memilih Poduk Tabungan Bank Syariah. Skripsi, Fakultas Ekonomi Bisnis Islam Institut Agama Islam Negeri Palopo, Palopo.

Rusdarti \& Kusmuriyanto. 2008. Ekonomi Fenomena Disekitar Kita. PT. Tiga Serangkai Pustaka Mandiri, Surakarta.

Sugiyono. 2012. Statistik Untuk Penelitian. Alfabeta. Bandung.

Sunyoto, D., 2014. Konsep Dasar Riset Pemasaran \& Perilaku Konsumen. 
CAPS (Center Of Academic Publishing Servce). Yogyakarta.

Suwiknyo, D. 2010. Analisis Laporan Keuangan Perbankan Syariah. Pustaka Pelajar. Yogyakarta.

Wardani, P. D., \& Susanti. 2019. Pengaruh Kontrol Diri, Religiusitas, Literasi Keuangan, Inklusi Keuangan Terhadap Perilaku Menabung Di Bank Syariah Mahasiswa Universitas Islam Negeri Sunan Ampel Surabaya. Jurnal Pendidikan Akuntansi, 07(02), p. 189-196.

Yuliani, M., \& Meliza, D. 2019. Partisipasi Mahasiswa Perbankan Syariah Universitas Islam Kuantan Singingi (UNIKS) Untuk Menabung di Bank Syariah Teluk Kuantan. Jurnal Tabarru' : Islamic Banking and Finance, 2(2), p. 50-59.

Zakariah, M. A., \& Vivi, A. 2021. Analisis Statistik Dengan SPSS Untuk Penelitian Kuantitatif. Yayasan Pondok Pesantren Al-Mawaddah Warrahmah, Kolaka. 